\title{
Metabolism of glucose by human embryos
}

\author{
R. G. Wales*, D. G. Whittingham, K. Hardy and I. L. Craft $\dagger$ \\ $M R C$ Unit of Experimental Embryology and Teratology, Carshalton, Surrey SM5 4EF, U.K. and \\ $\dagger I V F$ Unit, Cromwell Hospital, London SW5 0TU, U.K.
}

\begin{abstract}
Summary. Glucose turnover, as measured by $\mathrm{CO}_{2}$ production, lactate accumulation and carbon incorporation from $\left[\mathrm{U}^{14} \mathrm{C}\right]$ glucose as sole energy substrate, was low on the 2nd day of culture of human embryos resulting from in-vitro fertilization but above that of unfertilized oocytes. In general, all parameters of metabolism increased substantially during the following 2 days of development but the rate of increase in lactate production was greater than that of $\mathrm{CO}_{2}$, especially between Days 3 and 4 . Within developing embryos, no correlation was evident between the metabolic turnover of glucose and the method of patient stimulation, the morphological quality of embryos or the apparent rate of cleavage in culture. The results indicate that, before Day 3 of development, glucose is not effective as an energy source for the human embryo because of a blockade to glycolysis similar to that in mouse embryos.
\end{abstract}

\section{Introduction}

Since the early success of in-vitro fertilization and embryo transfer in the human (Edwards et al., 1980; Lopata et al., 1980; Wood et al., 1981), a large number of clinical units using the techniques has been established worldwide, offering a service to infertile couples.

The rate of fertilization of human oocytes aspirated from follicles is high (Trounson et al., 1982; Porter et al., 1984) as is the success of early cleavage (Trounson et al., 1982). However, the implantation rate of these embryos after embryo transfer is disappointing. Although up to $30 \%$ of patients receiving more than one embryo become pregnant (Edwards \& Steptoe, 1983), the rate of pregnancies per oocyte is only about 10\% (Speirs et al., 1982, Lopata, 1983; Kerin et al., 1983; Craft et al., 1984). Amongst the many factors that could contribute to this low rate of success, suboptimal conditions during culture might be important. Our present knowledge of the requirements of these embryos in culture is based on empirical findings, there being little, if any, scientific data available about the growth requirements.

Wales (1986) has described a method for studying substrate utilization by single mouse embryos. This technique has been used in the present study to investigate the metabolism of substrates by the human embryo during early cleavage and thus to provide some information on the substrate requirements of these embryos in vitro.

\section{Materials and Methods}

Oocytes and embryos used in this study originated for the routine in-vitro fertilization (IVF) programme at the Cromwell Hospital and were excess to the requirements of that programme. The work was carried out under approval from the Hospital's Ethics Committee, the Medical Research Council and subsequently the Voluntary Licensing Authority. All donations to the study were made after patient consent.

In the patients selected for IVF treatment at the Cromwell Hospital IVF Clinic, growth of multiple follicles was either induced by standard clomiphene and human menopausal gonadotrophin (HMG) treatment (Craft, 1984) or

*Present address: School of Veterinary Studies, Murdoch University, Murdoch, Western Australia 6150, Australia. 
by continuous infusion of buserelin (an analogue of luteinizing-hormone releasing-hormone; LHRH) followed by treatment with HMG or follicle-stimulating hormone (FSH) as described elsewhere (Porter et al., 1984).

The techniques for IVF and culture beyond the pronucleate stage are described elsewhere (Craft, 1984). For the patients whose oocytes were used in this study, a fertilization rate of $83 \%$ ( 278 of 366 oocytes recovered) was achieved. This is similar to the rates reported previously at this clinic (Ahuja et al., 1985). Fertilized oocytes were cultured in Eagle's medium (Gibco, Paisley, U.K.) usually supplemented with 10 or $20 \%$ cord serum. On a few occasions cord serum was replaced by human serum albumin $(2.5 \%$; Sigma Chemical Co., St Louis, MO, U.S.A.) plus pyruvate (0.45 mM).

The specimens available for study varied from unfertilized oocytes to early blastocysts and were transported from the hospital to the MRC Laboratories in capped plastic tubes (Falcon Plastics, Becton-Dickenson U.K. Ltd, Oxford, U.K.) at $35^{\circ}$ C. Eagle's medium was used for transport and the tubes were well gassed and sealed so that no pH change occurred. On arrival at the laboratory, $\sim 1 \mathrm{~h}$ after leaving the hospital, the embryos were transferred to cavity blocks and assessed on morphological appearance under a dissecting microscope; all relevant data on age, development, treatment and morphology were recorded. Degenerated and fragmented samples were rejected and the remaining embryos were scored as Class A or B. Those in Class A were embryos with normal morphological appearance for the stage of development, with blastomeres of similar size and no cytoplasmic fragments. Embryos placed in Class B had blastomeres of different sizes and/or one or more cytoplasmic fragments. All oocytes classified as unfertilized lacked pronuclei on inspection $18-20 \mathrm{~h}$ after the addition of spermatozoa to the oocytes.

After inspection, the embryos and oocytes were washed through three samples of bicarbonate-buffered, energyfree medium (Brinster, 1965) in preparation for the measurement of their metabolic turnover by using the radioisotopic techniques recently described in detail by Wales (1986). In summary, individual embryos were transferred to droplets of bicarbonate-buffered medium containing radiolabelled substrate and incubated for $2.5 \mathrm{~h}$ in small incubation flasks with $5 \% \mathrm{CO}_{2}$ in air as the gas phase. At the end of incubation, medium was acidified and $\mathrm{CO}_{2}$ absorbed with $\mathrm{NaOH}$. The embryo, medium and $\mathrm{CO}_{2}$ were then recovered and processed.

The metabolism of glucose by embryos was studied by following the metabolic fate of $\left[\mathrm{U}-{ }^{14} \mathrm{C}\right] \mathrm{glucose}$ of high specific activity ( $11 \mathrm{GBq} / \mathrm{mmol}$; Radiochemical Centre, Amersham, U.K.) added to substrate-free medium at a concentration of $0.56,0.28$ or $0.10 \mathrm{~mm}$. The production of $\mathrm{CO}_{2}$ and lactate from glucose and the incorporation of this substrate into embryos were calculated from the net counts in the respective fractions and the specific activity of the substrate. In a further small series of experiments the rate of entry of substrate into the citric acid cycle was assessed by measuring the production of ${ }^{14} \mathrm{CO}_{2}$ from DL-[ $\left[1{ }^{14} \mathrm{C}\right]$ lactate (Radiochemical Centre), added to substrate-free medium at a concentration of 1.2 or $4.9 \mathrm{~mm}$ and a specific activity of $2 \mathrm{GBq} / \mathrm{mmol}$.

For statistical purposes, the data for unfertilized oocytes were treated separately. The results obtained with developing embryos were then grouped according to the morphological appearance of the samples; the groups being 2-cell, 3-cell, 4-cell, 5-cell, 6-cell, 8-cell, 12-cell/morula and blastocyst. Bartlett's test on the data showed significant heterogeneity in the variances between groups for all characteristics measured. This heterogeneity was eliminated by logarithmic transformation. For this transformation, zero estimates were given a value equivalent to half the least significant difference in d.p.m. from control values. This was about equal to $0.01 \mathrm{pmol} / \mathrm{embryo}^{-1}$.

Within morphological groups, various subgroups could be identified for statistical purposes. In the first place, the data could be subgrouped depending on whether they were obtained from Class A or Class B embryos and whether the oocytes originated from patients given standard clomiphene/HMG treatment or from those stimulated by infusion of buserelin. Some asynchrony in the time required for embryos to reach a certain stage of development was also noted and embryos could be designated as fast or slow developers, the latter taking $\sim 24 \mathrm{~h}$ longer to reach the same stage of development.

As the number of samples studied depended on the availability of material, there was considerable variation in group size and the analyses of the data to test the effects of development and differences between the subgroupings within the developmental stages was carried out by the least squares method for unequal group size. For the analysis of $\mathrm{R} \times 2$ tables of data with disproportionate subclass numbers, the correct interaction sum of squares was computed directly and the sum of squares for main effects was adjusted before testing to take into account inequalities in means resulting from the unequal numbers in subclasses (Snedecor \& Cochran, 1967). Finally, a computer-programmed interactive multilinear regression analysis (Northwest Analytical Inc., OR, U.S.A.) was carried out on the appropriate data to find the polynomial regressions which gave the best fit to the changes observed during development.

\section{Results}

In all, successful incubations were carried out with 76 embryos and 18 unfertilized oocytes. A glucose concentration of $0.56 \mathrm{~mm}$ was used in 40 of these tests whilst 0.28 and $0.10 \mathrm{~mm}$ were used for 25 and 12 incubations respectively. The remaining 17 samples were used to estimate the production of carbon dioxide from $1 \cdot 12 \mathrm{~mm}-\left[1-{ }^{14} \mathrm{C}\right]$ lactate. Data on the production of $\mathrm{CO}_{2}$, the incorporation of substrate carbon and the accumulation of lactate from glucose by human oocytes and embryos incubated in medium containing $0 \cdot 56,0 \cdot 28$ or $0 \cdot 10 \mathrm{~mm}-\left[\mathrm{U}-{ }^{14} \mathrm{C}\right]$ glucose as sole energy substrate are given in Table 1. 
Table 1. $\mathrm{CO}_{2}$ produced, carbon incorporated and lactate accumulated from glucose by human embryos incubated for $2.5 \mathrm{~h}$ in medium containing glucose as sole energy substrate

\begin{tabular}{|c|c|c|c|}
\hline $\begin{array}{l}\text { Stage of } \\
\text { development }\end{array}$ & $\begin{array}{c}\mathrm{CO}_{2} \text { produced } \\
\left(\mathrm{pmol} / \mathrm{embryo}^{-1}\right)\end{array}$ & $\begin{array}{l}\text { Carbon incorporated } \\
\left(\text { pg atom/embryo } \mathrm{h}^{-1}\right)\end{array}$ & $\begin{array}{l}\text { Lactate accumulated } \\
\left(\mathrm{pmol} / \mathrm{embryo}^{-1}\right)\end{array}$ \\
\hline \multicolumn{4}{|c|}{ Embryos incubated in $0.56 \mathrm{~mm}$-glucose } \\
\hline 1-cell $\dagger$ & $0.12 \pm 0.07(4)$ & $0.21 \pm 0.02(4)$ & $0 \cdot 11 \pm 0.05(4)$ \\
\hline 2-cell & $0.43 \pm 0.40(2)$ & $0.76 \pm 0.58(2)$ & $0 \cdot 11 \pm 0.05(2)$ \\
\hline 3-cell & $0.61 \pm 0.27(2)$ & $0 \cdot 22$ & $0.01 \pm 0.01(2)$ \\
\hline 4-cell & $0.68 \pm 0.24(8)$ & $0.66 \pm 0.44(8)$ & $0.37 \pm 0 \cdot 16(8)$ \\
\hline 5-cell & $0.76 \pm 0.26(5)$ & $0.36 \pm 0.08(5)$ & $0.17 \pm 0.06(5)$ \\
\hline 6-cell & $4 \cdot 57 \pm 1 \cdot 13(6)$ & $0.68 \pm 0.19(5)$ & $6.29 \pm 4.37(6)$ \\
\hline 8-cell & $4.57 \pm 0.84(5)$ & $1 \cdot 34 \pm 0.18(6)$ & $6.01 \pm 1.73(6)$ \\
\hline Morula & $7 \cdot 10 \pm 2 \cdot 82(3)$ & $2.43 \pm 0.09(3)$ & $11.43 \pm 2.97(3)$ \\
\hline Blastocyst & $6.81 \pm 2.55(3)$ & $2 \cdot 59 \pm 0.85(3)$ & $36.53 \pm 13.55(3)$ \\
\hline \multicolumn{4}{|c|}{ Embryos incubated in $0.28 \mathrm{~mm}$-glucose } \\
\hline 1-cell $\dagger$ & $0.17 \pm 0.07(11)$ & $0.04 \pm 0.01(7)$ & $0.00 \pm 0.00(5)$ \\
\hline 2 -cell & $0.06 \pm 0.06(5)$ & $0.03 \pm 0.02(5)$ & $0.07 \pm 0.04(5)$ \\
\hline 3-celi & $0.84 \pm 0.47(2)$ & - & 0.22 \\
\hline 4-cell & 0.98 & 0.44 & $0 \cdot 32$ \\
\hline 6-cell & $2 \cdot 46 \pm 0.82(3)$ & 0.51 & $2.44 \pm 0.07(2)$ \\
\hline 8-cell & $2.48 \pm 0.48(3)$ & 0.38 & $2 \cdot 21$ \\
\hline Morula & $3.79 \quad$ (1) & $0 \cdot 76$ & $15 \cdot 40$ \\
\hline \multicolumn{4}{|c|}{ Embryos incubated in $0.10 \mathrm{~mm}$-glucose } \\
\hline 1 -cell & 0.04 & $0 \cdot 17$ & 0.00 \\
\hline 4-cell & $0.34 \pm 0.05(2)$ & $0 \cdot 29 \pm 0 \cdot 10(2)$ & $0 \cdot 26 \pm 0 \cdot 13(2)$ \\
\hline 8-cell & $0.38 \pm 0.02(2)$ & $0.26 \pm 0.01(2)$ & $0.49 \pm 0.24(2)$ \\
\hline Morula & $1.55 \pm 0.52(6)$ & $0.59 \pm 0.14(5)$ & $4 \cdot 56 \pm 2 \cdot 30(6)$ \\
\hline Blastocyst & 2.79 & $1 \cdot 19$ & $16 \cdot 4$ \\
\hline
\end{tabular}

Values are the means \pm s.e.m. (number of observations).

$\dagger$ Not fertilized.

Before proceeding with a statistical analysis of the data, it was considered appropriate to attempt to group the data by age to reduce the number of developmental categories and to provide a logical grouping of the morphological stages isolated. As fertilization was confirmed by finding pronuclei about $18 \mathrm{~h}$ after insemination, Day 1 of pregnancy might be considered as extending from 18 to $42 \mathrm{~h}$ after insemination, Day 2 from 42 to $66 \mathrm{~h}$, Day 3 from 66 to $80 \mathrm{~h}$ and Day 4 from 80 to $104 \mathrm{~h}$, with Day 0 being the day of insemination of the oocyte. The embryonic stages between 2 and 5 cells had an average lapsed time from insemination to incubation of $60 \pm 3 \mathrm{~h}(n=27)$ and so were considered as Day-2 embryos, 6- to 8-cells with a lapsed time of $80 \pm 3 \mathrm{~h}(n=20)$ as Day-3 embryos and morulae/blastocysts $(97 \pm 5 \mathrm{~h}, n=14)$ as Day-4 embryos. Statistical analysis of the time from insemination to incubation showed no significant differences between the morphological stages within these groups. Furthermore, using the results obtained from incubations in $0.56 \mathrm{~mm}$ glucose, analysis of the metabolic data for the developmental stages from 2- to 5-cell (Day 2) showed no significant difference in $\mathrm{CO}_{2}$ production $\left(\mathrm{F}_{3,13}=0.45\right)$, glucose incorporation $\left(F_{3,12}=0.20\right)$ or lactate accumulated $\left(F_{3,13}=1 \cdot 69\right)$. Similarly, 6- and 8-cell embryos (Day 3) did not differ significantly in the values for these metabolic parameters nor did morulae and blastocysts (Day 4). A summary of the results grouped by days and prepared for statistical analysis is given in Table 2.

Statistical analysis of the results sorted by grade of embryo (Class A or B) or by asynchrony of development (fast or slow developers) failed to show significant differences between the subgroups so isolated (Table 3). Statistical analysis also showed that there was no effect of method of stimulation (clomiphene/HMG or by continuous infusion of buserelin) on the parameters measured. 
Table 2. Summary of the metabolism of glucose by human embryos sorted by developmental age

\begin{tabular}{|c|c|c|c|c|}
\hline \multirow{2}{*}{$\begin{array}{l}\text { Metabolic } \\
\text { parameter }\end{array}$} & \multirow{2}{*}{$\begin{array}{c}\text { Stage of } \\
\text { development }\end{array}$} & \multicolumn{3}{|c|}{ Glucose concentration (mм) } \\
\hline & & 0.56 & $0 \cdot 28$ & $0 \cdot 10$ \\
\hline $\begin{array}{l}\mathrm{CO}_{2} \text { produced } \\
\left(\mathrm{pmol} \text { embryo } \mathrm{h}^{-1}\right)\end{array}$ & $\begin{array}{l}\text { Day } 2 \\
\text { Day } 3 \\
\text { Day } 4\end{array}$ & $\begin{array}{l}0.42(17) \\
4 \cdot 12(11) \\
5 \cdot 65(6)\end{array}$ & $\begin{array}{l}0.08(8) \\
2.31(6) \\
3.79(1)\end{array}$ & $\begin{array}{l}0 \cdot 31(2) \\
0 \cdot 38(2) \\
1 \cdot 14(7)\end{array}$ \\
\hline $\begin{array}{l}\text { Carbon incorporation } \\
\left(\text { pg atom/embryo h }{ }^{-1}\right)\end{array}$ & $\begin{array}{l}\text { Day } 2 \\
\text { Day } 3 \\
\text { Day } 4\end{array}$ & $\begin{array}{l}0 \cdot 32(16) \\
0 \cdot 89(11) \\
2 \cdot 12(6)\end{array}$ & $\begin{array}{l}0.04(6) \\
0.44(2) \\
0.76(1)\end{array}$ & $\begin{array}{l}0.27(2) \\
0.26(2) \\
0.59(6)\end{array}$ \\
\hline $\begin{array}{l}\text { Lactate accumulation } \\
\left(\text { pmol/embryo } h^{-1}\right)\end{array}$ & $\begin{array}{l}\text { Day } 2 \\
\text { Day } 3 \\
\text { Day } 4\end{array}$ & $\begin{array}{c}0 \cdot 11(17) \\
3 \cdot 51(10) \\
18 \cdot 20(6)\end{array}$ & $\begin{array}{r}0.06(7) \\
2.36(3) \\
15.4(1)\end{array}$ & $\begin{array}{l}0.22(2) \\
0.42(2) \\
2.01(7)\end{array}$ \\
\hline
\end{tabular}

Values are the antilogarithm of means obtained from the $\log _{10}$ transformed data as used in the regression analysis in Table 4.

Table 3. Statistical analyses of the data in Table 2 to test the effect of class of embryo or asynchrony in development on the metabolic turnover of glucose by human embryos

\begin{tabular}{|c|c|c|c|c|c|c|c|}
\hline \multirow{2}{*}{\multicolumn{2}{|c|}{ Source of variation }} & \multicolumn{2}{|c|}{$\begin{array}{c}\mathrm{CO}_{2} \\
\text { produced }\end{array}$} & \multicolumn{2}{|c|}{$\begin{array}{c}\text { Carbon } \\
\text { incorporated }\end{array}$} & \multicolumn{2}{|c|}{$\begin{array}{c}\text { Lactate } \\
\text { accumulated }\end{array}$} \\
\hline & & d.f. & $\mathrm{F}$ & d.f. & $\mathbf{F}$ & d.f. & $\mathbf{F}$ \\
\hline \multirow[t]{5}{*}{ (1) } & $\begin{array}{l}\text { Test of class of embryo } \\
\text { (0.56 mM-glucose) }\end{array}$ & & & & & & \\
\hline & Class A vs. Class B & 1 & $0 \cdot 11$ & 1 & 0.03 & 1 & 0.01 \\
\hline & Between days & 2 & $26 \cdot 12^{* *}$ & 2 & $14 \cdot 32^{* *}$ & 2 & $40 \cdot 06^{* *}$ \\
\hline & Interaction & 2 & $2 \cdot 18$ & 2 & 0.74 & 2 & 0.22 \\
\hline & Within cells (error) & 27 & $0 \cdot 158$ & 25 & 0.116 & 27 & $0 \cdot 330$ \\
\hline \multirow[t]{5}{*}{ (2) } & $\begin{array}{l}\text { Test of asynchrony } \\
\text { (all concentrations) }\end{array}$ & & & & & & \\
\hline & Effect of asynchrony & 1 & 0.01 & 1 & 0.95 & 1 & 1.76 \\
\hline & Between groups & 6 & $11 \cdot 00^{* *}$ & 5 & $12 \cdot 52^{* *}$ & 6 & $16 \cdot 41^{* *}$ \\
\hline & Interaction & 6 & 0.50 & 5 & 0.72 & 6 & 0.85 \\
\hline & Within cells (error) & 33 & 0.280 & 30 & 0.144 & 30 & $0 \cdot 325$ \\
\hline
\end{tabular}

$* * P<0.01$.

In view of the lack of significant differences between these subgroups, the combined data for each parameter was subjected to a regression analysis (Colquhoun, 1971) to isolate the effect of glucose concentration on metabolic turnover and its interaction with developmental age. Significant differences in metabolism as a result of changing the concentration of glucose were found and there was, overall, a linear increase in metabolism with time. However, the linear regression of metabolism with time varied with glucose concentration and there were either significant deviations from linearity or interaction of this effect with time. Therefore, separate regression analyses for each measure at each glucose concentration were undertaken and these lines are presented in Table 4. Except at $0.10 \mathrm{~mm}$-glucose, all values showed a significant linear increase with time. The regression equations and their errors are also given in Table 4 and the calculated regression lines at $0.56 \mathrm{~mm}$-glucose are compared with the experimental data in Fig. 1.

By combining the data with suitable weightings, it is possible to make an estimate of the total glucose metabolized per embryo. On Day 2, total turnover of glucose was low irrespective of the concentration of glucose in the medium and did not exceed $2 \mathrm{pg}$ atoms of glucose carbon/embryo 
Table 4. Regression analysis and regression equations for the change in metabolic parameters with development for Day 2 to Day 4 embryos

\begin{tabular}{|c|c|c|c|c|c|c|c|c|c|}
\hline \multirow[b]{3}{*}{$\begin{array}{l}\text { Source of } \\
\text { variation }\end{array}$} & \multicolumn{9}{|c|}{ Variance ratios } \\
\hline & \multicolumn{3}{|c|}{$0.56 \mathrm{~mm} \cdot$ glucose } & \multicolumn{3}{|c|}{$0.28 \mathrm{~mm}$-glucose } & \multicolumn{3}{|c|}{$0.10 \mathrm{~mm}$-glucose } \\
\hline & $\underset{\text { prod'n }}{\mathrm{CO}_{2}}$ & $\begin{array}{l}\text { Carbon } \\
\text { incorp. }\end{array}$ & $\begin{array}{l}\text { Lactate } \\
\text { accum. }\end{array}$ & $\underset{\operatorname{prod}^{\prime} \mathrm{n}}{\mathrm{CO}_{2}}$ & $\begin{array}{l}\text { Carbon } \\
\text { incorp. }\end{array}$ & $\begin{array}{l}\text { Lactate } \\
\text { accum. }\end{array}$ & $\underset{\text { prod'n }}{\mathrm{CO}_{2}}$ & $\begin{array}{l}\text { Carbon } \\
\text { incorp. }\end{array}$ & $\begin{array}{l}\text { Lactate } \\
\text { accum. }\end{array}$ \\
\hline \multicolumn{10}{|l|}{ Between days } \\
\hline Linear & $50 \cdot 23^{* *}$ & $32 \cdot 15^{* *}$ & $89 \cdot 23^{* *}$ & $12 \cdot 77^{* *}$ & $6 \cdot 83^{*}$ & $27 \cdot 66^{* *}$ & $3 \cdot 25$ & $5 \cdot 30$ & $2 \cdot 85$ \\
\hline Other & $7 \cdot 76^{* *}$ & 0.06 & 3.68 & 1.53 & $2 \cdot 16$ & 0.76 & 0.35 & 0.78 & $0 \cdot 10$ \\
\hline $\begin{array}{l}\text { Within days } \\
\text { (error) }\end{array}$ & $\begin{array}{l}0 \cdot 16 \\
(1: 31)\end{array}$ & $\begin{array}{l}0 \cdot 10 \\
(1: 32)\end{array}$ & $\begin{array}{l}0 \cdot 31 \\
(1: 34)\end{array}$ & $\begin{array}{l}0.59 \\
(1: 12)\end{array}$ & $\begin{array}{l}0 \cdot 33 \\
(1: 6)\end{array}$ & $\begin{array}{l}0 \cdot 30 \\
(1: 8)\end{array}$ & $\begin{array}{l}0 \cdot 18 \\
(1: 8)\end{array}$ & $\begin{array}{l}0.07 \\
(1: 7)\end{array}$ & $\begin{array}{l}0.60 \\
(1: 8)\end{array}$ \\
\hline
\end{tabular}

${ }^{* *} P<0.01$. The degrees of freedom associated with the tests of the variance ratios are given in parentheses at the base of each column.

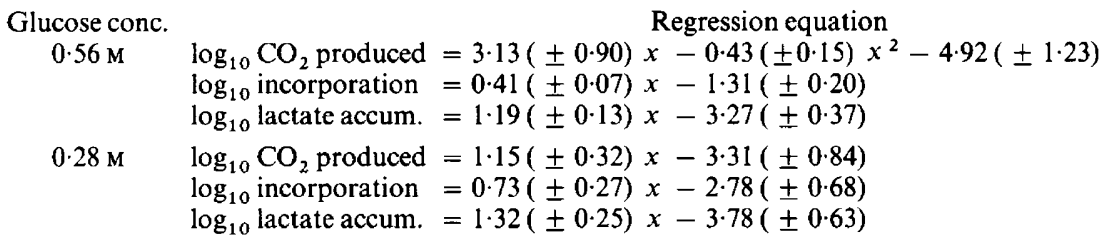

Table 5. Data for incubations in the presence of $0.56 \mathrm{~mm}$-glucose calculated on a per cell basis

\begin{tabular}{|c|c|c|c|}
\hline $\begin{array}{l}\text { Stage of } \\
\text { development }\end{array}$ & $\begin{array}{c}\mathrm{CO}_{2} \text { produced } \\
\left(\mathrm{pmol}^{-} / \mathrm{cell}^{-1}\right)\end{array}$ & $\begin{array}{l}\text { Carbon incorporated } \\
\left(\mathrm{pg} \text { atom } / \text { cell } \mathrm{h}^{-1}\right)\end{array}$ & $\begin{array}{l}\text { Lactate accumulated } \\
\left(\mathrm{pmol} / \mathrm{cell} \mathrm{h}^{-1}\right)\end{array}$ \\
\hline Day 2 & $0.17 \pm 0.04(17)$ & $0.16 \pm 0.06(16)$ & $0.06 \pm 0.02(17)$ \\
\hline Day 3 & $0.68 \pm 0.11(11)$ & $0.14 \pm 0.02(11)$ & $0.90 \pm 0.37(12)$ \\
\hline Day 4 & $0.33 \pm 0.10 \quad(6)$ & $0.13 \pm 0.01 \quad(6)$ & $0.95 \pm 0.22$ \\
\hline
\end{tabular}

Values are the means \pm s.e.m. (no. of observations).

$\mathbf{h}^{-1}$. At the later stages of development, glucose utilization was substantial and proportional to the concentration in the medium. For example on Day $4,17 \mathrm{pg}$ atoms of glucose carbon were metabolized/embryo $\mathrm{h}^{-1}$ at $0.56 \mathrm{~mm}$-glucose. Thus, at the incubation volume used $(\sim 500 \mathrm{nl})$, utilization of glucose never exceeded $15 \%$ of the total substrate available in the medium. By comparison of these data for total utilization with the data in Table 1, the proportion of glucose utilized that was metabolized to $\mathrm{CO}_{2}$ or lactate, or was incorporated, could be calculated. Similar trends were found at all concentrations. On Day 2, approximately equal amounts of glucose carbon were metabolized to $\mathrm{CO}_{2}$ and lactate and about $25 \%$ of the glucose utilized was incorporated into the embryo. However, by Day 4 , about $90 \%$ of the glucose carbon metabolized was found as lactate, irrespective of the glucose concentration used. At this stage, $10 \%$ of the glucose carbon was metabolized to $\mathrm{CO}_{2}$ and only $1-4 \%$ was incorporated into the embryo.

The metabolic data were also calculated on the basis of turnover/cell $h^{-1}$ (Table 5). In the absence of direct cell counts on the Day 4 embryos used in the study, morulae and blastocysts were considered as 16- and 32-cell embryos respectively for the purpose of these calculations. Analysis of the data for morphological stages within days showed no significant differences between stages for any of the values measured. Between days, $\mathrm{CO}_{2}$ production reached a peak on Day 3 , falling to half this value on Day 4. There was a 15-fold increase in lactate accumulated between Days 2 and 3 but little change thereafter. Carbon accumulated, however, showed no significant change over the developmental period studied. 


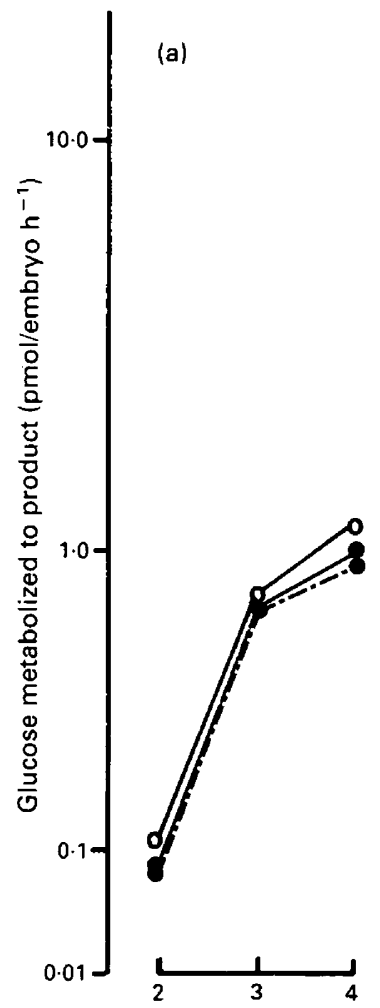

(b)

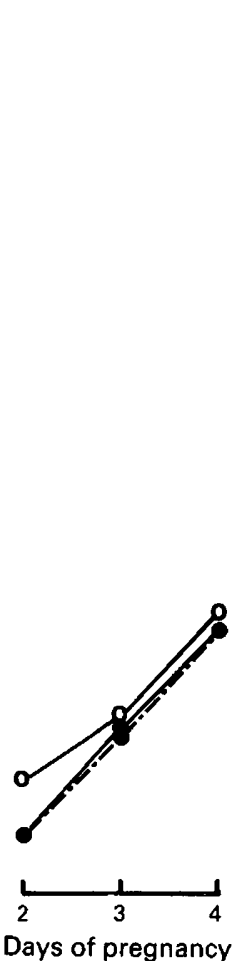

(c)

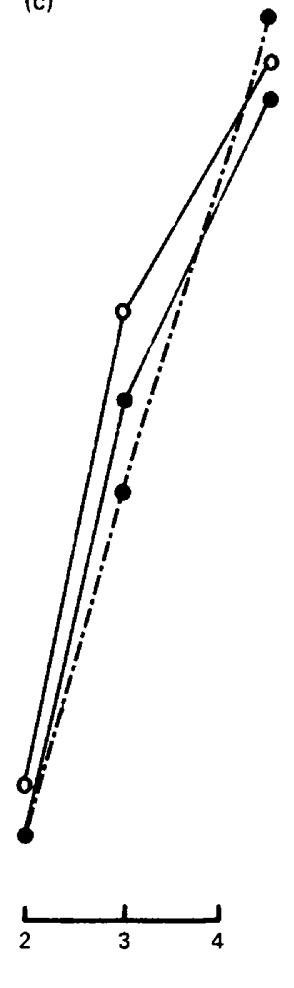

Fig. 1. Amounts of glucose metabolized to carbon dioxide (a), incorporated into the embryo (b), and accumulated as lactate in the medium (c), during a 2.5-h incubation of human embryos in the presence of $0.56 \mathrm{~mm}$-glucose. $\mathrm{O}-\mathrm{O}$, Means of untransformed data; -0 , antilogarithm of the means of transformed data; -- antilogarithm of the value calculated from the regression equation.

Table 6. $\mathrm{CO}_{2}$ produced from the carbon one position of lactate during $2.5 \mathrm{~h}$ incubation of human embryos in media containing DL- $\left[1-{ }^{14} \mathrm{C}\right]$-lactate as sole energy substrate

\begin{tabular}{|c|c|c|}
\hline $\begin{array}{l}\text { Lactate conc. } \\
\text { (mM) }\end{array}$ & $\begin{array}{c}\text { Stage of } \\
\text { development }\end{array}$ & $\begin{array}{c}\mathrm{CO}_{2} \text { produced } \\
\left(\mathrm{pmol} / \mathrm{embryo}^{-1}\right)\end{array}$ \\
\hline $\begin{array}{l}1 \cdot 2 \\
1 \cdot 2 \\
1 \cdot 2 \\
1 \cdot 2 \\
1 \cdot 2 \\
1 \cdot 2\end{array}$ & $\begin{array}{l}- \\
\text { 2-cell } \\
3 \text {-cell } \\
4 \text {-cell } \\
\text { 5-cell } \\
8 \text {-cell }\end{array}$ & $\begin{array}{l}1.07 \pm 0.02(2) \\
1.90 \pm 0.55(4) \\
1.04 \pm 0.68(3) \\
1.94 \pm 0.28(8) \\
1.45 \quad(1) \\
0.66 \pm 0.09(3)\end{array}$ \\
\hline $\begin{array}{l}4 \cdot 9 \\
4 \cdot 9\end{array}$ & $\begin{array}{r}3 \text {-cell } \\
7-8 \text {-cell }\end{array}$ & $\begin{array}{c}5 \cdot 2 \\
6 \cdot 35 \pm 0.32(2)\end{array}$ \\
\hline
\end{tabular}

Values are the means \pm s.e.m. (number of observations). 
Finally, the amount of carbon-one of lactate liberated as $\mathrm{CO}_{2}$ during a $2.5 \mathrm{~h}$ incubation in the presence of $\left[1-{ }^{14} \mathrm{C}\right]$ lactate is shown in Table 6 . Analysis of the data using $1.2 \mathrm{~mm}$-lactate in the medium failed to indicate any significant differences in the amount of $\mathrm{CO}_{2}$ produced between the stages of development tested or between these embryos and unfertilized oocytes. Furthermore, the limited data obtained using 4.9 mm-lactate suggests that the rate of entry of this substrate into the citric acid cycle is concentration dependent. The mean value for $\mathrm{CO}_{2}$ producted at $4.9 \mathrm{~mm}$ $\left(5.97 \mathrm{pmol} / \mathrm{embryo}^{-1}\right)$ was four times that at $1.2 \mathrm{~mm}\left(1.51 \mathrm{pmol} / \mathrm{embryo}^{-1}\right)$.

\section{Discussion}

The embryos obtained for this study were additional to those required for immediate transfer. Since no embryo storage facility existed at the time, they were made available but only with the patient's consent. As such they may be considered as a biased sample because those embryos with the best morphological appearance would have been used for transfer and further development in vivo. To help reduce problems of bias in samples, embryos were selected for use on morphology and, within those selected, samples were classified as A or B embryos. Those within the former classification had the best morphology and were those most likely to have been selected for transfer. Class B embryos were specimens that might have been used for transfer had the numbers of oocytes collected from a particular patient been low. These two classes of embryo were indistinguishable on the measures used in this study and appear equally competent to utilize external metabolic substrates. As both classes of embryo have been reported to be capable of producing successful pregnancies (I. L. Craft, unpublished observations), it may be difficult to distinguish embryos capable of further development from others, either on morphological or simple biochemical measures; once embryos showing frank degeneration have been eliminated.

The present embryos derived from in-vitro fertilization showed a degree of asynchrony in development with some embryos reaching a particular morphological stage up to $24 \mathrm{~h}$ later than might have been expected. This retardation or asynchrony appears to have no obvious biochemical penalty as analysis of substrate utilization after sorting each morphological stage by age failed to highlight differences due to age. Indeed, this retardation in development may be more apparent than real and could arise as a result of differences in the time of fertilization of oocytes aspirated at various stages of maturation. This suggestion is strengthened by the finding that, in the Cromwell IVF programme, some oocytes classified as unfertilized $16 \mathrm{~h}$ after insemination, do subsequently fertilize and cleave when reinseminated at this time.

When the average time from fertilization to incubation for each morphological stage was calculated, the embryos fell into three groups approximately equivalent to Days 2, 3 and 4 of pregnancy. The first two cell divisions were completed on Day 2, the third by the end of Day 3, with further division and compaction occurring on Day 4. This is similar to the time course of events for mouse embryos and indicates a similar length of the cell cycle in these species.

The major part of the present study was undertaken using media containing $0.56 \mathrm{~mm}$-glucose. The supplementary experiments using lower concentrations showed that, in general, metabolism of this substrate was linearly related to substrate concentration. Calculation of total substrate utilized to that available in the micro-droplet showed that, even at the highest rates of turnover, only $\leqslant 15 \%$ of substrate available was utilized. The rate of utilization over the concentration examined would therefore appear to depend on substrate transport into the embryo rather than restriction of substrate availability.

From studies of glucose utilization in the mouse (Brinster, 1967; Pike \& Wales, 1982; Wales, 1986), one might expect to find some increase in glucose turnover in human embryos at substrate concentrations above $0.56 \mathrm{~mm}$. However, Pike \& Wales (1982) noted that the membrane carrier system involved in glucose uptake remains close to saturation when the glucose level in the environment is reduced from $5.0 \mathrm{~mm}$ to $0.5 \mathrm{~mm}$. The latter concentration was chosen in the present studies 
as a compromise between maximizing turnover and maintaining a high specific activity to increase the reliability of the relative assessment of substrate turnover.

Whilst there were no significant differences in the catabolic metabolism of glucose between morphological stages within days of development, there were substantial differences between days except at the lowest concentration of glucose tested. At this concentration, recovery of metabolites approached the limits of sensitivity of the methods and time trends were not significant. Little turnover of glucose by the unfertilized oocyte could be demonstrated at any substrate concentration, isotope recovery in these samples being close to the level in background incubations. Day- 2 embryos utilized more glucose than did unfertilized oocytes but turnover was still low and more $\mathrm{CO}_{2}$ was produced than lactate accumulated. Substantial increases in $\mathrm{CO}_{2}$ production and lactate accumulation occurred between Days 2 and 3. A further substantial increase in lactate formation occurred between Days 3 and 4 so that, by Day 4, the majority of glucose utilized appeared as lactate. These trends, coupled with the evidence for adequate functioning of the TCA cycle activity in the early embryo, as assessed by lactate decarboxylation, suggest that in the early human embryo, as in the mouse, there is a blockade to glycolysis which is removed with development (Barbehenn et al., 1974).

Whilst glucose catabolism follows similar patterns in mouse and human embryos, there are noteworthy quantitative differences. In the human, the metabolic constraints on glycolysis disappear $24 \mathrm{~h}$ earlier than reported in the mouse (Brinster, 1967; Wales, 1968, 1986) with the greatest relative change between Day 2 and 3. Furthermore, if the data of Brinster (1967) and Wales (1968, 1986) are recalculated to give rates of turnover per cell for comparison with those presented in Table 5, a contrasting pattern of incorporation emerges. Whilst turnover per cell in human embryos reached a peak on Day 3, that in the mouse was considerably lower on this day than on the preceding or succeeding days. The possible significance of these changes for the metabolic economy of the embryos is yet to be determined.

Of all the measures of glucose metabolism, incorporation was the most consistent. The amount of substrate incorporated approximately doubled every $24 \mathrm{~h}$. The constant rate of incorporation per cell at all stages studied suggests that carbon from this substrate is being incorporated at a steady rate into the structural components of blastomeres. It might therefore be argued that glucose could act as a significant source of substrate carbon for anabolic reactions within the cell during early development. However, the data on catabolic utilization of glucose presented here suggest that this substrate is unlikely to be able to satisfy energy requirements during early cleavage. Notwithstanding this observation, several media containing little or no alternative substrate to glucose have been used successfully in human IVF programmes. If, like the mouse, the early human embryo requires simpler substrates such as lactate and/or pyruvate for cleavage, they must originate under these conditions from the metabolic conversion of glucose by the spermatozoa and cumulus cells, a conversion shown' to occur both in the human (K. K. Ahuja \& D. Gilburt, unpublished observations) and the mouse (Donahue \& Stern, 1968). However, in the absence of more definitive data, the addition of lactate and/or pyruvate to the media would seem to be a wise precaution to help optimize the conditions of culture for human embryos during the first cleavage divisions.

R. G. W. thanks the Medical Research Council for the provision of laboratory facilities, the Royal Society and Nuffield Foundation for financial aid, and Murdoch University for the support of his Outside Studies Programme.

\section{References}

Ahuja, K.K., Smith, W., Tucker, M. \& Craft, I. (1985) Successful pregnancies from the transfer of pronucleate embryos in an outpatient in vitro fertilization program. Fert. Steril. 44, 181-184.
Barbehenn, E.K., Wales, R.G. \& Lowry, O.H. (1974) The explanation for the blockade of glycolysis in early mouse embryos. Proc. natn. Acad. Sci. U.S.A. 71, 1056-1060. 
Brinster, R.L. (1965) Studies on the development of mouse embryos in vitro II The effect of energy source. J. exp. Zool. 158, 59-68.

Brinster, R.L. (1967) Carbon dioxide production from glucose by the preimplantation mouse embryo. Expl Cell. Res. 47, 271-277.

Craft, I. (1984) In vitro fertilization; clinical methodology. Br. J. Hosp. Med. 31, 90-102.

Craft, I., Porter, R., Green, S., Tucker, M., Smith, B., Twigg, H., Ahuja, K. \& Whittingham, D. (1984) Success of fertility, embryo number, and in vitro fertilization. Lancet i, 732 .

Colquhoun, C. (1971) Lectures in Biostatistics. Oxford University Press, London.

Donahue, R.P. \& Stern, S. (1968) Follicular cell support of oocyte maturation: production of pyruvate in vitro. J. Reprod. Fert. 17, 395-398.

Edwards, R.G. \& Steptoe, P.C. (1983) Current status of in vitro fertilization and implantation of human embryos. Lancet ii, 1265-1269.

Edwards, R.G., Steptoe, P.C. \& Purdy, J.M. (1980) Establishing full-term human pregnancies using cleaving embryos grown in vitro. Br. J. Obstet. Gynaec. 87, 737-756.

Kerin, J.F., Warnes, G.M., Quinn, P.J., Jeffrey, R., Kirby, C., Matthews, C.D., Seamark, R.F. \& Cox, L.W. (1983) Incidence of multiple pregnancy after in vitro fertilization and embryo transfer. Lancet ii, 537-540.

Lopata, A. (1983) Concepts in human in vitro fertilization and embryo transfer Fert. Steril. 40, 289-301.

Lopata, A., Johnson, I.W.H., Hoult, I.J. \& Speirs, A.I. (1980) Pregnancy following intrauterine implantation of an embryo obtained by in vitro fertilization of a preovulatory egg. Fert. Steril. 33, 117-120.
Pike, I.L. \& Wales, R.G. (1982) Uptake and incorporation of glucose especially into the glycogen pools of preimplantation mouse embryos during culture in vitro. Aust. J. biol. Sci. 35, 195-206.

Porter, R.N., Smith, W., Craft, I.L., Abdulwahid, N.A. \& Jacobs, H.S. (1984) Induction of ovulation for in vitro fertilization using buserelin and gonadotrophins. Lancet ii, 1284-1285.

Speirs, A.L., Lopata, A., Gronow, M.J., Kellow, G.N. \& Johnson, W.I.H. (1982) Analysis of the benefits and risks of multiple embryo transfer. Fert. Steril. 39, $468-471$.

Snedecor, G.W. \& Cochran, W.G. (1967) Statistical Methods, 6th edn. Iowa State University Press, Ames.

Trounson, A.O., Mohr, L.R., Wood, C. \& Leeton, J.F. (1982) Effect of delayed insemination on in-vitro fertilization, culture and transfer of human embryos. J. Reprod. Fert. 64, 285-294.

Wales, R.G. (1968) Accumulation of carboxylic acids from glucose by the preimplantation mouse embryo. Aust. J. biol. Sci. 22, 701-707.

Wales, R.G. (1986) Measurement of metabolic turnover in single mouse embryos. $J$. Reprod. Fert. 76, $717-725$.

Wood, C., Trounson, A., Leeton, J., Talbot, J.McK., Buttery, B., Webb, J., Wood, J. \& Jessup, D. (1981) A clinical assessment of nine pregnancies obtained by in vitro fertilization and embryo transfer. Fert. Steril. 35, 502-508.

Received 10 June 1986 